\title{
SCULPTING A COMMUNITY FOR TOURISM ENTERPRISE: A CASE STUDY IN LENGGONG VALLEY, MALAYSIA
}

\author{
Mastura Jaafar \\ Universiti Sains Malaysia \\ Alireza Jalali* \\ University of Nizwa \\ Norziani Dahalan \\ Universiti Sains Malaysia \\ Sara Abhari \\ Universiti Sains Malaysia
}

\begin{abstract}
Entrepreneurship training is an integral element that promotes entrepreneurship across a wide range of industries. In rural areas, the success of tourism destination heavily and solely depends on community involvement. Hence, community-based tourism enterprise (CBTE) appears to be a practical approach in encouraging the community to be involved in entrepreneurial activities. Nevertheless, efforts are scarce to document the training modules of CBTE program established in rural tourism. This study, hence, explored the training modules for CBTE development in the Lenggong Valley and measured the effectiveness of the training. The program has been initiated by Universiti Sains Malaysia (USM) with cooperation from Northern Corridor Economic Implementation (NCIA). The CBTE training was successfully conducted, wherein the community had placed high ranking for most of the items. The identified main challenge refers to sustenance of the business entity. This article contributes to CBTE literature by sharing a new perspective pertaining to training modules within the context of rural tourism. The study outcomes may be utilised by other CBTE programs with some modification to suit their specific needs and requirements.
\end{abstract}

Keywords: Community-Based Tourism Enterprise, Entrepreneurship, Rural Tourism, Lenggong Valley.

Received: 8 October 2018

Accepted: 29 October 2020

https://doi.org/10.33736/ijbs.3191.2021

\section{INTRODUCTION}

Tourism industry is an important tool for community development that assists communities to improve their economy, to enjoy better standard of living, and to provide vast opportunities for the

\footnotetext{
- Corresponding author: Department of Management, Collage of Economic, Management and Information system, University of Nizwa; Address: Room number 11- H- 3, Collage of Economic, Management and information System, University of Nizwa, Birkat Al Mouz, Nizwa, Sultanate of Oman, P.O. Box 33, PC 616; Email: arjiaa@yahoo.com
} 
locals to be involved in rural tourism development, particularly in delivering tourism services and products (Jaafar, Md Noor, Mohamad, Jalali, \& Hashim, 2020). Community-based tourism (CBT) has been identified as a popular local community engagement method within the tourism sector, which has been widely recognised as a viable vehicle for improvement in rural areas (Zielinski, Jeong, \& Milanés, 2020). The CBT signifies a type of tourism that offers high levels of community participation under the sustainability umbrella. The CBT is often linked to rural tourism as communities in rural areas typically refer to those with the propensity to work together on community projects (Kayat \& Zainuddin, 2016).

Community-based enterprise (CBE) has been either mentioned or applied in a vast range of studies concerning CBT that refers to the enterprise itself or initiatives (Zielinski et al., 2020; JaramilloMoreno et al., 2020; Jaafar et al., 2020; Mtapuri \& Giampiccoli, 2013; Sebele, 2010). The idea of $\mathrm{CBE}$ involves communities that function as both enterprise and entrepreneur; as part of a venturing process in pursuit of economic and social goals (Peredo \& Chrisman, 2006). The CBTE attempts to arrange the community by taking advantage of the whole touristic requests, which has been reckoned as a significant medium for upgrading rural growth (Jaramillo-Moreno et al., 2020; Giampiccoli \& Kalis, 2012). Jaafar et al. (2020) asserted that CBTEs are small- and medium-sized enterprises (SMEs) that can positively influence social and economic development in rural areas. Mitchell and Ashely (2010) denoted that CBTEs with strong business plan, reliable technical support, good business training, as well as wide incentive market linkages and flow of funds, can generate significant yields.

Prior studies have proven that entrepreneurship is integral for industry development, wherein entrepreneurship can be developed via education. According to Ladzani and Van Vuuren (2002), deficiency of training has been acknowledged as the main reason for enterprise failure. Jaafar, Abu Bakar, and Wan Daud (2015) depicted that the success of entrepreneurs after establishing their own enterprises depends on their attendance in various courses and seminars. Attending courses and seminars for business start-ups ascertains smooth operation of business (Ali, 2011). Attending short courses can be considered as informal education, which is a crucial tool in providing excellent exposure and information to those striving to become an expert, skilful, and well-trained entrepreneur. One advantage of informal education is mentoring relationship with experienced entrepreneurs (Lucchetti \& Font, 2013). Exchanging ideas and opinions, participating in first-hand learning, and sharing experience with fellow participants are some beneficial practices that can be applied to achieve business longevity in future (Mano, Iddrisu, Yoshino, \& Sonobe, 2012).

Training refers to the process of consistently gaining knowledge linked with job, skills, and attitude to perform special tasks effectively (Mullins, 2010). According to Osuagwu (2006), skills required by entrepreneurs can be divided into three primary areas; technical skills, business management, and personal entrepreneurial skills. Technical skills include writing, listening, oral presentation, organising, coaching, being a game player, and technical know-how; whereas business management skills involve starting, developing, and managing enterprise; and personal entrepreneurial skills reflect the ability to take risk, creativity, persistency, innovative, and vivid vision for growth (Ladzani \& Van Vuuren, 2002). In line with this, Ogundele, Akingbade, and Akinlabi (2012) discovered a positive correlation between entrepreneurship training and poverty reduction in Nigeria. They concluded that entrepreneurship training can empower entrepreneurs by enhancing their knowledge and skills to yield maximum output. 
This paper embarked on a case study which delved into the training program for CBTE development in the Lenggong Valley, Malaysia. Lenggong Valley has been reckoned as a World Cultural Heritage Site by the United Nations Educational, Scientific, and Cultural Organisation (UNESCO) in June 30, 2012 due to its rich archaeological heritage (Rasoolimanesh, Dahalan, \& Jaafar, 2016). Typical in rural areas, the main socioeconomic activities of local community are related to agricultural. A majority of the community is still involved in first-level socioeconomic activities, such as deer and prawn farming, durian and rubber plantation, and fisheries, which in average contribute to their low-level income. Community development is a major concern for UNESCO recognition, whereby such recognition should be able to bring value-added element to the community. According to Jaafar et al., (2020), Lenggong residents have also been involved in small family businesses, such as handicrafts and small food manufacturing, in which some have been involved in business for generations. Nevertheless, the contribution of these activities has not flourished in the Lenggong Valley. Since the establishment of UNESCO site until the time of this study, only a handful of existing businesses in Lenggong Valley seem to support the competitiveness of this UNESCO site. With this in mind and several justifications listed in Section 2.3, USM has been pursuing the goal to transform the bottom billions within the community to achieve sustainable socio-economic well-being. In precise, the Lenggong Valley was selected based on the need to enhance the aspect of competitiveness in the Lenggong Valley as a UNESCO destination. The unique physical and cultural assets can be transformed into specific products and activities to add value for tourist attraction. Following that, USM has taken the initiative to start its CBTE program with budget granted by the Northern Corridor Implementation Authority (NCIA). The NCIA has been established as the authority responsible for providing direction, as well as devising policies and strategies related to socioeconomic development in the Northern part of Peninsular Malaysia. In this program, the NCIA offered some funding to purchase the necessary equipment for production and training, while the USM equipped knowledge and budget for researchers to run the program, and the community prepared trainees, venue, and networking. Two villages were selected based on specific justifications, such as the readiness of the community leader and the members for participation, agreement on product selection, available resources (e.g., raw material and community hall), existence of business entity, and capital support. The program was run between October 2016 and $30^{\text {th }}$ September 2018. A university approach in developing the CBTE program across Malaysian rural areas is rarely highlighted by scholars. Developing a CBTE training program is unique based on specific requirements that depend on the product proposed, the condition of rural areas, the types of resources, and the various stakeholders.

Exploration on specific CBTE training program is still lacking in the tourism literature. The gap remains on the knowledge concerning training conducted for CBTE, particularly in Malaysia. The main objectives of this study are listed as follows:

1. To explore the training program conducted for creating CBTEs in Lenggong Valley, Malaysia

2. To assess the community's perception on the effectiveness of this training program

Essentially, this article discusses tourism entrepreneurship before delineating entrepreneurship training and followed by a case study on CBTE entrepreneurship training in Lenggong Valley. The remaining of this paper is organised as follows. The next section reviews the relevant literature with respect to community involvement in tourism entrepreneurship, the necessity of entrepreneurship training, and entrepreneurship training in the Lenggong Valley. Next, the 
research method is explained in section three. The penultimate section presents the analysis and results, while the last section covers the discussion.

\section{LITERATURE REVIEW}

\subsection{Tourism entrepreneurship}

Entrepreneurship is a central force of economic growth with a significant role in rural development (Jalali, Jaafar, \& Ramayah, 2020; Jaafar et al., 2020). For tourism to sustain in rural areas, the residents must be willing to take part in tourism entrepreneurship (Galvao, Marques, Ferreira, \& Braga, 2020). Hence, the roles of government and local community in exerting effort to push for entrepreneurship are essential for rural development. In this case, entrepreneurial action reflects generation of resources or combining the existing resources to develop and to commercialise new products for new consumers and markets (Schendel \& Hitt, 2007). The local residents can contribute to develop tourism entrepreneurship by creating and delivering products yielded by local enterprises, utilising some of the profits generated by the tourism industry to enhance the socioeconomic of its community members or by continually using tourism products generated by local entrepreneurs (Nicely \& Sydnor, 2015).

Tourism is often viewed as beneficial to rural communities, despite several predicted deficiencies, including human capital, limited access to decision-making, and funding (Jaafar et al., 2020; Zielinski et al., 2020). Many studies have highlighted the importance of tourism entrepreneurship in rural tourism development. According to Johnson (2010), social-economy enterprises developed from tourism development have been used to develop capacity in multiple areas of rural economies and to deliver community services. A significant way to develop rural areas is through social economy and social-economy enterprises. The $\mathrm{CBE}$, for instance, offers vast services and products for both locals and tourists (Zielinski et al., 2020; Jaafar, Kayat, Tangit, \& Yacob, 2013; Johnson, 2010).

It is significant to distinguish the traditional perspectives of entrepreneurship research domain that emphasise on traits and characteristics of the entrepreneur from what an entrepreneur actually does as an individual (Jalali, Thurasamy, \& Jaafar, 2017; Jalali, Jaafar, \& Thurasamy, 2013; Jalali, Jaafar, \& Ramayah, 2014), wherein an alternative approach that recognises entrepreneurial activity may occur at group level (Haugh \& Pardy, 1999). Entrepreneurship by groups of individuals reflects entrepreneurial venture teams (Haugh \& Pardy, 1999). Johannisson (2011) describes the notion of entrepreneur as a collective of creative process manipulated by the actions and interactions of agents, as well as their physical, social, and historical environments. According to Gunawan, Eko, Yudistyana, and Putri (2020), the concept of community-as-entrepreneur denotes the effort of the community members that meets the community needs to enjoy a high degree of control over activities, which contradicts the profit motivation inherent entrepreneurship theorisation deriving from market economics.

\subsection{Tourism entrepreneurship and the process of community involvement}

Community is defined as a society with similar cultures, values, and interests in relation to social identification and region that all members respect and recognise (Rodrigues \& Prideaux, 2018). 
Involvement in a community is critical for the success of CBTE, mainly because the abundance of natural resources and recognition of the region are embedded in their cultural knowledge (Taylor, 2017; Lee \& Jan, 2019). One of the most significant goals of CBTE is to ensure that individual members of the local communities possess the ability to control all tasks taking place in their local area and receive equal proportion of the economic benefits (Scheyvens, 2002). According to Jaafar et al. (2020), members of a host community should be involved in CBTE because they have historical understanding of how the region adapts to change, will be the ones most closely affected by tourism, and the expectation to be an integral part of the tourism product. Ideally, community participation is composed of modelling improvement so that the predesigned beneficiaries are at the front line, participating by involving both tangible and intangible resources, making their own decisions, identifying their own essential requirements, and managing those processes (Stone, 1989).

Nonetheless, communities face challenges in their participation, such as insufficiencies related to product design and marketing their product, limited access to specific information, as well as lack of managerial skills and investment capital (Imbaya, Nthiga, Sitati, \& Lenaiyasa, 2019). Mgonja, Sirima, Backman, and Backman (2015) identified that lack of appropriate managerial skills linked with product development, marketing, customer relationship, and financial management are the major challenges in successful CBTE projects. Rodrigues and Prideaux (2018) asserted that when communities have adequate entrepreneurial skills and access to resources, they have the prospect of becoming active participants in tourism development. Active community involvement presents more opportunities for them to control and protect their interests and their regions (Scheyvens, 2002). Lee and Jan (2019) highlighted that the way local residents perceive the influence of tourism is crucial for the successful development of CBTE. Their direct interaction with tourists may result in memorable tourist experiences, which later can affect tourism planning and improvement in that area. Tosun (2000) pointed out that the implementation of sustainable tourism development principles, including participation in CBTE, stipulates more possibilities for local individuals to obtain profits from tourism improvements that take place in their local area. However, there are proven cases where communities are not eager to participate in CBTEs when monetary or nonmonetary awards are absent, such as new skill development, increased confidence level and trust, as well as project ownership (Stone \& Stone, 2011).

\subsection{The necessity of entrepreneurship training}

Due to rapid changes of circumstances, business owners and entrepreneurs should be trained at all levels of the business, wherein these training programs should positively influence on owners' entrepreneurial awareness, intentions, aptitude, and success, as well as entrepreneurship behaviour (Galvao et al., 2020). Asah, Fatoki, and Rungani (2015) and Jalali et al., (2020) depicted that business owners must improve their managerial skills, such as financial management, marketing, strategic planning, human resource management, networking, and organising skills (administrative ability), to enhance the business environment and to address changes as they happen. Kroon and Moolman (1992) stated that participation in seminar and courses aids an entrepreneur to learn solving certain problems, as well as becoming more aware of certain rules and procedures that may be of great help in business. Success in small business training is typically measured in terms of knowledge and skills, training delivery, acquisition by recipients, change in behaviour as a result of learning, and behaviour that changes business performance (Friedrich, Glaub, Gramberg, \& Frese, 2006). They added that workshops on entrepreneurial should focus on personal 
competencies and behavioural indicators, which include the following: opportunity seeking and initiative, risk-taking, demand for quality efficiency, persistence, commitment, goal setting, systematic planning and monitoring, persuasion and networking, independence, and selfconfidence.

Kurczewska and Mackiewicz (2020) revealed that identifying new market opportunities, coming up with new products by generating new ideas, acquiring new clients through presentation of goods, cooperating with other people, managing people, displaying leadership quality, working under uncertainty or stress, as well as addressing crisis and financial management, are essential in determining the success or failure of entrepreneurs. The aspects of motivation, qualities, and skills of a management have an impact on the way a firm is (mis) managed. Insufficient and inappropriate skills of management may lead to failure in many firms. With expertise in only limited areas and unwillingness to accept professional advice tend to decrease the probability of a firm its chances to survive (Ooghe \& De Prijcker, 2008). Arasti, Zandi, and Bahmani (2014) revealed that lack of managerial skills, such as marketing, financial, strategic management, and business skills, was ranked as the second most important factor for unsuccessful entrepreneurs after inappropriate policy. Lack of training amongst entrepreneurs has been the primary reason for business failure. According to Gupta (1989), trained entrepreneurs recorded a failure rate of below 10 percent, when compared to 25 percent amidst other small enterprises and 80 percent amongst trained entrepreneurs who reaped profits, as opposed to 60 percent of the other enterprises.

\subsection{Case study: Entrepreneurship training on CBTE in Lenggong Valley}

The program was initiated to develop local community business by transforming their socioeconomic lifestyle. After acknowledging the Lenggong Valley as a UNESCO site, the number of visitors to Galeri Arkeologi Lembah Lenggong had hiked up to $40.5 \%$ in 2014 (80,925), in comparison to that in 2013 (57,597). The significance of the program is justified to: (1). Create a business entity that is bound to enhance the cottage industry and offer new job opportunities to the community; (2). Provide new and relevant activities and products to support the tourism development sector in Lenggong Valley; (3). Provide new source of income that may hinder the youths from migrating to urban areas since the involvement of youth in conservation is an imminent agenda for the Lenggong Valley (Jaafar., Md Nor, \& Rasoolimanesh, 2015); (4). Protect traditional heritage value in hand craft and food by completely utilising the raw resources available in Lenggong; and (5). Support national development and competitiveness of Lenggong Valley. As such, two villages were selected for the program; Kampung Luat and Kampong Raban. The aim of the program is that each village should generate two products in accordance to gender. The women in Kampung Luat focused on traditional food, while hand craft from mengkuang leaves in Kampung Raban. As for the men, those from Kampung Luat made wood craft and those from Kampung Raban yielded printed craft. The program involved 32 participants from both villages.

The program was scheduled in three phases. The first phase refers to the preliminary phase that composed of signing of NCIA-USM agreement, signing of USM community memorandum of understanding, providing supplies for training, and procuring materials. The second phase included the training of product design and labelling. Finally, in the third phase, the facilitators offered advice to the local community regarding product and business model development, as well as the significance of keeping in touch with both government and private sectors. This paper presents the assessment of training program conducted at Phase 2. 
Table 1 lists the modules developed for the training program. The first week was the introductory course on entrepreneurship that looked into creating and managing business entity. These modules exposed the trainees to various business opportunities derived from UNESCO acknowledgement of the Lenggong Valley. The module focused on business registration and the primary principle in managing a business. The second week focused on product development. Each product was introduced by a facilitator regarding hands-on application with machineries and equipment. The participants were involved in generating the products. The third week was about marketing and branding. The trainees had to design their product label, determine the price per unit product, and develop their business cash flow. Lastly, the fourth week emphasised on a trial marketing week for market testing. The training was conducted from $9^{\text {th }}$ January to $22^{\text {nd }}$ February 2017 . From time to time, USM and NCIA monitored their sales volume to ensure that they reach the capacity of machine usage and product sales.

Table 1: Details of training development

\begin{tabular}{|c|c|c|c|}
\hline Week 1 & Week 2 & Week 3 & Week 4 \\
\hline $\begin{array}{l}\text { MODULE 1 } \\
\text { Understanding } \\
\text { Entrepreneurial Concepts }\end{array}$ & & $\begin{array}{l}\text { MODULE } 8 \\
\text { Product Design \& Branding } \\
\text { (Computer Design) }\end{array}$ & $\begin{array}{l}\text { Product } \\
\text { selling }\end{array}$ \\
\hline $\begin{array}{l}\text { MODULE } 2 \\
\text { Identify opportunities \& } \\
\text { Generate business ideas }\end{array}$ & & $\begin{array}{l}\text { MODULE } 9 \\
\text { Presentation of goods } \\
\text { Packaging and labelling }\end{array}$ & \\
\hline $\begin{array}{l}\text { MODULE } 3 \\
\text { Business registration } \\
\text { Related laws } \\
\text { business ethics }\end{array}$ & $\begin{array}{l}\text { MODULE } 7 \\
\text { Product } \\
\text { Development } \\
\text { Wood craft } \\
\text { Traditional food } \\
\text { Printed craft } \\
\text { Hand craft }\end{array}$ & $\begin{array}{l}\text { MODULE } 10 \\
\text { Skills and principles of selling \& } \\
\text { practical sales } \\
\text { - Conventional sales } \\
\text { - Online sales } \\
\text { - Other methods of sale }\end{array}$ & \\
\hline $\begin{array}{l}\text { MODULE } 4 \\
\text { Business operation and } \\
\text { people management } \\
\text { MODULE 5 } \\
\text { Marketing (4Ps) } \\
\text { Product, Price, Promotion } \\
\text { and Place } \\
\text { MODULE 6 } \\
\text { Financial management }\end{array}$ & & $\begin{array}{l}\text { MODULE } 11 \\
\text { Record preparation } \\
\text { - attendance } \\
\text { - Purchase of raw materials } \\
\text { - Wages } \\
\text {-Financial } \\
\text { - Sales revenue }\end{array}$ & \\
\hline
\end{tabular}

\section{METHODOLOGY}

The quantitative approach was adopted in this study to gather primary data. The demographic profile and feedback given on the training modules by the trainees involved in the entrepreneurship training program conducted in the Lenggong Valley were analysed. The training program was scheduled for five days in a week and held from 2 PM to 6 PM. The schedule was suggested by the trainees since they were involved in their routine activities in the morning. The primary data 
collection tool for this study was designed to evaluate their agreement level on the usefulness of the training program. The questionnaire was divided into two sections; the first section assessed the background of the respondents, while the second section measured their perceptions in light of entrepreneurship training effectiveness, including issues related to each module namely understanding entrepreneurship concepts, opportunity identification and new business ideas, business registration (law and business ethics), business operation and people management, marketing-product, price, promotion, place, financial management, product development, productbranding, packaging and labelling, marketing, and record keeping. A five-point Likert scale ranging from 1 (strongly disagree) to 5 (strongly agree) was used to collect responses from the participants in the third section of the questionnaire. The unit of analysis for this study comprised of the trainees and the survey questionnaires distributed to the respondents after week three of the program. The questionnaires were delivered by hand and the participants were given 30 minutes to complete the questionnaire. A total of 32 trainees had participated in the entrepreneurship program and full response was obtained. The respondents provided answers for all questions embedded in the questionnaires. The low number of participants can be justified based on the two following points: 1) only a small number of individuals had agreed to participate in this project, and 2) it was challenging to identify the right participants in the range of 30-50 years of age due to migration of the local population to urban areas. Nevertheless, having 32 trainees in a workshop is adequate for product training and development program. Following the data collection, the Statistical Packages for Social Science (SPSS) version 24 was employed to conduct descriptive statistics analysis, which included frequency, percentage, and standard deviation of the gathered data.

\section{ANALYSIS}

Table 2 tabulates the demographic profile of the trainees involved in entrepreneurship training held at the Lenggong Valley. In terms of gender, the number of males was equivalent to that of females. Besides, equal distribution in terms of age category was noted. Most of them were engaged in various types of socio-economic activities, while only five were housewives.

Table 2: Demographic Profile of the Trainees

\begin{tabular}{cccc}
\hline \hline Description & Criteria & Frequency & Percentage \\
\hline Gender & Male & 16 & 50 \\
& Female & 16 & 50 \\
Age & $20-25$ & 6 & 18.8 \\
& $26-30$ & 6 & 18.8 \\
& $31-35$ & 2 & 6.3 \\
& $36-40$ & 5 & 15.6 \\
& $41-45$ & 1 & 3.1 \\
\multirow{5}{*}{ Occupation } & 51 and above & 12 & 37.5 \\
& Self-employed & 25 & 78.1 \\
& Housewife & 5 & 15.6 \\
& Others & 2 & 6.3 \\
\hline \hline
\end{tabular}


Table 3 displays the feedback provided by the trainees regarding the training modules. Based on the retrieved feedback, all trainees agreed on the effectiveness of the training provided.

Table 3: Perceptions of trainees on training effectiveness

\begin{tabular}{|c|c|c|}
\hline $\begin{array}{c}\text { Description } \\
\end{array}$ & Frequency & Standard Deviation \\
\hline \multicolumn{3}{|l|}{ MODULE 1: UNDERSTANDING } \\
\hline \multicolumn{3}{|l|}{ ENTREPRENEURSHIP CONCEPTS } \\
\hline $\begin{array}{l}\text { 1- The invited speaker area corresponds to the } \\
\text { program }\end{array}$ & 4.41 & .499 \\
\hline 2- Speakers provide relevant examples & 4.50 & .508 \\
\hline 3- The duration of the lecture is satisfactory & 4.53 & .567 \\
\hline 4- Speakers interact with course participants & 4.59 & .560 \\
\hline 5- Speakers provide high motivational value & 4.44 & .504 \\
\hline \multicolumn{3}{|l|}{ MODULE 2: OPPORTUNITY } \\
\hline \multicolumn{3}{|l|}{ IDENTIFICATION AND NEW BUSINESS } \\
\hline \multicolumn{3}{|l|}{$I D E A S$} \\
\hline $\begin{array}{l}\text { 6- Participants are ready to develop product } \\
\text { related to tourism industry development }\end{array}$ & 4.13 & .751 \\
\hline $\begin{array}{l}\text { 7- Participants are interested in marketing } \\
\text { tourism attractions }\end{array}$ & 4.06 & .801 \\
\hline $\begin{array}{l}\text { 8- Business opportunities in Lenggong Valley } \\
\text { are potentially high }\end{array}$ & 3.88 & .907 \\
\hline \multicolumn{3}{|l|}{ MODULE 3: BUSINESS REGISTRATION } \\
\hline 9- Participants understand the types of business & 4.03 & .695 \\
\hline $\begin{array}{l}\text { 10- Participants are informed about the } \\
\text { establishment / registration of the business }\end{array}$ & 4.06 & .669 \\
\hline \multicolumn{3}{|l|}{ MODULE 4: BUSINESS OPERATIONS AND } \\
\hline \multicolumn{3}{|l|}{ PEOPLE MANAGEMENT } \\
\hline $\begin{array}{l}\text { 11- Disclosures about business entity (company } \\
\text { / cooperative / club) }\end{array}$ & 4.09 & 689 \\
\hline $\begin{array}{l}\text { 12- Understand the functional task in business } \\
\text { organisation }\end{array}$ & 4.09 & .689 \\
\hline \multicolumn{3}{|l|}{ MODULE 5: MARKETING - PRODUCT, } \\
\hline 13- Knowledge of selling products & 4.19 & .780 \\
\hline 14- Calculation of sale price and profit & 4.03 & .782 \\
\hline 15- The importance of marketing in business & 4.22 & .832 \\
\hline 16- Determination of business location & 3.94 & .716 \\
\hline \multicolumn{3}{|l|}{ MODULE 6: FINANCIAL MANAGEMENT } \\
\hline 17- Learn how to manage company finances & 4.13 & .793 \\
\hline $\begin{array}{l}\text { 18- Know the importance of financial } \\
\text { management }\end{array}$ & 3.56 & .672 \\
\hline \multicolumn{3}{|l|}{ MODULE 7 PRODUCT DEVELOPMENT } \\
\hline 19- Able to create product & $4 . .37$ & .914 \\
\hline \multicolumn{3}{|l|}{$\begin{array}{l}\text { MODULES } 8 \text { and 9- PRODUCT BRANDING, } \\
\text { PACKAGING AND LABELLING }\end{array}$} \\
\hline 20- Understand product branding & 4.32 & 0.78 \\
\hline $\begin{array}{l}\text { 21- Given advise on creating product branding } \\
\text { and packaging }\end{array}$ & 4.44 & 0.726 \\
\hline
\end{tabular}




\begin{tabular}{|c|c|c|}
\hline 22- Understand the importance of labelling & 4.02 & 0.83 \\
\hline MODULE 10-MARKETING & & \\
\hline $\begin{array}{l}\text { 23- Understand the various methods of } \\
\text { marketing }\end{array}$ & 3.52 & .632 \\
\hline MODULE 11 - RECORD KEEPING & & \\
\hline 24- Understand business record keeping & 3.20 & 0.723 \\
\hline
\end{tabular}

Scale: 1-Strongly disagree to 5-strongly agree

Table 4 shows the feedback given by the participants according to five-point Likert scale. The respondents seemed to have understood modules 1 until 4, and their level of comprehension began to decrease for modules 5 to 9. Their level of understanding was the lowest for modules 10 and 11. Since most of them were self-employed, their feedback mostly revolved around the general modules on speakers, business opportunities and set up, when compared to specific modules on marketing, finance, and product development. More importantly, most of the participants were satisfied with product modules (modules 7 to 9), which provides them the opportunity to perform hands-on activities or producing product.

Table 4: Distribution of responses based on five-point Likert Scale

\begin{tabular}{|c|c|c|c|c|c|}
\hline Description/5 Likert-Scale & 1 & 2 & 3 & 4 & 5 \\
\hline \multicolumn{6}{|l|}{ MODULE 1: UNDERSTANDING } \\
\hline \multicolumn{6}{|l|}{ ENTREPRENEURSHIP CONCEPTS } \\
\hline $\begin{array}{l}\text { 1- The invited speaker area corresponds to the } \\
\text { program }\end{array}$ & 0 & 0 & 0 & 19 & 13 \\
\hline 2- Speakers provide relevant examples & & & & 16 & 16 \\
\hline 3- The duration of the lecture is satisfactory & 0 & 0 & 1 & 13 & 18 \\
\hline 4- Speakers interact with course participants & 0 & 0 & 1 & 11 & 20 \\
\hline 5- Speakers provide high motivational value & 0 & 0 & 0 & 18 & 14 \\
\hline \multicolumn{6}{|l|}{ MODULE 2: OPPORTUNITY } \\
\hline \multicolumn{6}{|l|}{ IDENTIFICATION AND NEW BUSINESS IDEAS } \\
\hline $\begin{array}{l}\text { 6- Participants are ready to develop product } \\
\text { related to tourism industry development }\end{array}$ & 0 & 1 & 4 & 17 & 10 \\
\hline $\begin{array}{l}\text { 7- Participants are interested in marketing tourism } \\
\text { attractions }\end{array}$ & 1 & 0 & 3 & 20 & 8 \\
\hline $\begin{array}{l}\text { 8- Business opportunities in Lenggong Valley are } \\
\text { potentially high }\end{array}$ & 1 & 2 & 0 & 3 & 20 \\
\hline \multicolumn{6}{|l|}{ MODULE 3: BUSINESS REGISTRATION (LAW } \\
\hline \multicolumn{6}{|l|}{ AND BUSINESS ETHICS) } \\
\hline 9- Participants understand the types of business & 1 & 1 & 0 & 25 & 5 \\
\hline $\begin{array}{l}\text { 10- Participants are informed about the } \\
\text { establishment / registration of the business }\end{array}$ & 1 & 0 & 0 & 26 & 5 \\
\hline \multicolumn{6}{|l|}{ MODULE 4: BUSINESS OPERATIONS AND } \\
\hline \multicolumn{6}{|l|}{ PEOPLE MANAGEMENT } \\
\hline $\begin{array}{l}\text { 11- Disclosures about business entity (company / } \\
\text { cooperative / club) }\end{array}$ & 1 & 0 & 0 & 25 & 6 \\
\hline $\begin{array}{l}\text { 12- Understand the functional task in business } \\
\text { organisation }\end{array}$ & 1 & 0 & 0 & 25 & 6 \\
\hline \multicolumn{5}{|l|}{ MODULE 5: MARKETING - PRODUCT, } & \\
\hline 13- Knowledge of selling products & 1 & 0 & 1 & 20 & 10 \\
\hline
\end{tabular}




\begin{tabular}{|c|c|c|c|c|c|}
\hline 14- Calculation of sale price and profit & 1 & 1 & 3 & 21 & 7 \\
\hline 15- The importance of marketing in business & 1 & 2 & 0 & 17 & 12 \\
\hline 16-Determination of business location & 1 & 2 & 0 & 3 & 20 \\
\hline \multicolumn{6}{|l|}{ MODULE 6: FINANCIAL MANAGEMENT } \\
\hline 17- Learn how to manage company finances & 1 & 3 & 0 & 24 & 4 \\
\hline $\begin{array}{l}\text { 18- Know the importance of financial } \\
\text { management }\end{array}$ & 1 & 2 & 0 & 20 & 9 \\
\hline \multicolumn{6}{|l|}{ MODULE 7 PRODUCT DEVELOPMENT } \\
\hline 19-Able to create product & 0 & 0 & 4 & 28 & 0 \\
\hline \multicolumn{6}{|l|}{$\begin{array}{l}\text { MODULES } 8 \text { and 9- PRODUCT BRANDING, } \\
\text { PACKAGING AND LABELLING }\end{array}$} \\
\hline 20-Understand product branding & 2 & 0 & 3 & 14 & 13 \\
\hline $\begin{array}{l}\text { 21-Given advise on creating product branding } \\
\text { and packaging }\end{array}$ & 0 & 0 & 0 & 18 & 14 \\
\hline 22-Understand the importance of labelling & 1 & 1 & 0 & 25 & 5 \\
\hline \multicolumn{6}{|l|}{ MODULE $10-$ MARKETING } \\
\hline 23-Understand the various methods of marketing & 4 & 6 & 0 & 13 & 9 \\
\hline \multicolumn{6}{|l|}{ MODULE $11-$ RECORD KEEPING } \\
\hline 24- Understand business record keeping & 5 & 5 & 3 & 13 & 6 \\
\hline
\end{tabular}

Cross tabulation was conducted based on the three demographic variables of respondents, namely gender, occupation, and age. As for the gender category, the responses seemed to strike a balance between male and female. In terms of occupation, as most of them were self-employed, the responses had insignificant variance between the groups and similar outcomes were observed for respondents from different age categories.

The NCIA spelt out the condition for the community to create business entity, along with sustenance and continuous business progress. The business entity must be led by one who directly monitored the project progress. For the case of Kampung Luat, the community already has Koperasi Wawasan Kg Luat to run the business, while the community in Kampung Raban had set up a special business entity under the youth club called Kelab Belia Kampung Raban (BARA). These two business entities must have their own bank account number and organisational structure.

Referring to Tables 1 and 3, in Week 1, the trainees were exposed to business environment, as well as setting up and managing their business plans. Module 1 received the highest feedback amongst all modules. Perhaps, the module is general and they enjoyed listening to various experiences or success stories narrated by the trainers. Module 2 focuses on business opportunity identification, while Module 3 delineates running a business. In Modules 1 and 2, successful entrepreneurs from the industry were invited as speakers. One of the speakers shared his experience dealing with tourists in managing his craft business at the UNESCO site in Georgetown. The other two speakers were experienced entrepreneurs from the food and hand craft industries.

Next, Modules 4 until 6 highlight company management. The feedback received from trainees was at a satisfactory level. An item each in marketing and financial management modules received rather low feedback, when compared to the other items. The said items were 'determination of business location' (mean=3.94) and 'know the importance of company financial management' $($ mean=3.56). 
Module 7 was introduced at four varied venues and was conducted by different facilitators. The product development stage gave opportunities for the trainees to use specific machine and equipment to produce their desired products. Basically, the products for men involved machinery, whereas food and hand craft required skills. The trainees were exposed to product development starting from preparing raw materials until product completion. These items scored a mean value of 4.37 .

In Week 3, the trainees were exposed to Modules 8 until 11. Modules 8 and 9 emphasise on graphic computer design conducted at the Cyber Centre located in Kampung Raban. Only selected trainees took part due to the limited number of computers available and not all displayed interest towards knowledge on computer skills. Hence, only the youth from Kampung Raban were involved in this phase. Meanwhile, other trainees were exposed to the idea of creating their own product branding. They were interested in their product branding and successfully created their product brands (mean = 4.44). Modules 10 and 11 facilitate in developing awareness amongst the trainees about marketing and book keeping. These two modules received rather low ranking; 3.52 and 3.20 mean values, respectively. Lastly, in week 4, the community began selling their products. The following illustrates the brands generated for the four different products:

Table 4: Types of products and their branding

Hand craft mengkuang

Product: Tudung saji

Kampung Raban

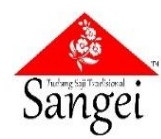

Printing craft

Product: T-shirt, Mug, Ceramic plate, Key-chain

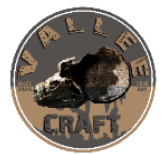

\section{Food}

Product: Kebebe and Ikan Pindang

Kampung Luat

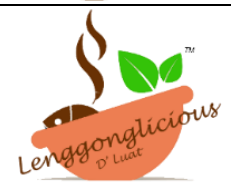

Wood craft

Product: Sarung Golok

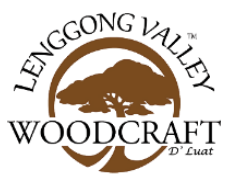

The cross tab analysis was performed to identify the differences for the different categories of gender, age, and socioeconomic activities. The trainees were composed of 16 male and female each. 


\section{DISCUSSION AND CONCLUSION}

The literature review points out the significance of training in enhancing knowledge concerning business amongst trainees (Galvao et al., 2020). The literature highlights that people with diverse skills and experience are more likely to establish a business (Kurczewska \& Mackiewicz, 2020). Researchers identified three essential aspects of knowledge, namely technical skills, business management, and personal entrepreneurial skills, wherein this particular training program covered all the three knowledge areas. This article adds knowledge to the complete module and training programs developed for CBTE in rural development. Being a UNESCO heritage destination, the Lenggong Valley should be supported with SME entities in satisfying the vast range of tourist needs. The existence of these entities is deemed to enhance the competitive advantage of tourism destination. This program, thus, has successfully developed new business entities for the purpose of creating new tourism-related products in the Lenggong Valley.

Comprehensive training was conducted for three consecutive weeks and good support was received by the community. In total, 32 trainees exhibited full commitment by participating in the training. It can be said that the objectives of the program have been met at the end of the training program. Their satisfaction level was high for most of the modules. The results of the descriptive statistics analysis revealed that the level of satisfaction among the participants for module 1 (understanding of entrepreneurship), module 2 (identify opportunities and generate business ideas), and module 3 (business registration) was very high. This result is in agreement with that stated in prior studies (Baroncelli \& Landoni, 2019; Sullivan, 2000), which found mentoring as indispensable to support new entrepreneurs by providing the right guidance and assistance. Successful entrepreneurs were invited to share their experience in conducting their businesses. According to Sullivan (2000), exposure from successful entrepreneurs offers useful insights on the beneficial understanding of running a new business based on their past experience. Entrepreneurial learning takes place during the new venture creation process and successful entrepreneurs are exceptional learners who learn from other entrepreneurs regarding opportunity identification and new idea creation (Baroncelli \& Landoni, 2019).

The study outcomes revealed that the participants were satisfied with module 4 (business operation and people management), module 5 (marketing), and module 6 (financial management). These modules assisted the participants in expanding their abilities in terms of managerial skills. These results are in line with a prior study (Asah, Fatoki, \& Rungani, 2015) which highlighted the need for business owners to develop their managerial skills, such as financial management, marketing, strategic planning, human resource management, networking, and organising skills (administrative ability). For example, financial management skills empower CBTE members to borrow some funds instead of employing self-funding in preparing their start-up capital (Castro \& Ferreira, 2019). Next, marketing skills in CBTE are extremely imperative to attract attention from consumers (Pato \& Kastenholz, 2017). The recognition of inadequate skills in running a CBTE project implies that communities should welcome training courses in related areas. Therefore, this training is indeed in need to enhance the skills and competencies of the trainees, so as to inculcate their interests and entrepreneurial motivations for business sustenance. However, according to North and Smallborn (2006), the programs must be designed based on specific modules and essential local requirements.

After the training, the communities were expected to start selling their products. The most challenging aspect is to encourage the community to sell their products after week 4 . The USM 
team had guided and assisted them by introducing their products at various events within district and state levels. Another challenge was exposing them to various types of marketing strategies. They seemed to heavily rely on the conventional marketing strategies in selling their products. Besides, several lacking areas were identified, such as record keeping, working culture, and less emphasis on product quality, as they were still tied to their traditional way of doing things. This is in contrast with the needs outlined by NCIA, wherein the business must be focused, monitored, possess viable business strategies, and display progress. In the attempt of supporting local tourism development, these business entities should grow and sustain with the support of a wide range of stakeholders, as well as private and public agencies.

In conclusion, entrepreneurship can indeed be trained. Nonetheless, the primary challenges lie in keeping the community motivated to ascertain business sustenance. The CBTE is based on the commitment displayed by each trainee that continuously keeps them motivated, which is of utmost significant. Apart from that, relationships established with other local government agencies, such as FAMA, Jabatan Perikanan, and Peladang - essential stakeholders, must be considered for product enhancement and marketing. With those placed in limelight, the NCIA has allocated 2 years for USM to monitor and to assist the local community in terms of their sustainable business entities. The NCIA has set target for the community to produce their business exit plan before the project ends. At the time this article is composed, the project is at Phase 3, where USM and NCIA are still involved in research and development activities, apart from religiously monitoring their record keeping, product quality, and promotion. One of the main shortcomings refers to the inability to explain how the trainees perceived this CBTE project as this project is still on-going and under assessment. Despite this limitation, it is hoped that the valuable findings presented in this article serve as a starting point for future studies in determining the influential factors of training program acceptance level. Future research work may probe into several other important factors, including income level, level of education, business experience, entrepreneurial motives and intentions, as well as ease of starting a business. The discussion raised a few unexplored topics related to entrepreneurship training program, which present interesting avenues for further investigation. For instance, future research may add more modules to the training program, which include leadership, crisis management, ability to work under uncertainty, ability to investigate new market opportunities, business environment analysis, and risk management. Due to the untapped research area of CBTE training, this paper serves as a platform for future studies concerning entrepreneurship training in the context of UNESCO archaeological site in Malaysia.

\section{ACKNOWLEDGMENT}

The authors would like to extend their appreciation to Universiti Sains Malaysia (USM) and Northern Corridor Implementation Authority (NCIA)-community for the research grants entitled (RU Top down grant no: 1001/PPBGN/870046) and (NCIA grant no.304: PPBGN.650840.N 111) that have made this paper possible. 


\section{REFERENCES}

Ali, R. (2011). Entrepreneurship-related factors and firm performance: A study on the Bumiputera housing developers in Peninsular Malaysia. (Unpublished doctoral dissertation), University Sains Malaysia, Malaysia.

Arasti, Z., Zandi, F., \& Bahmani, N. (2014). Business failure factors in Iranian SMEs: Do successful and unsuccessful entrepreneurs have different viewpoints? Journal of Global Entrepreneurship Research, 4(10), 2-14.

Asah, F., Fatoki, O. O., \& Rungani, E. (2015). The impact of motivations, personal values and management skills on the performance of SMEs in South Africa. African Journal of Economic and Management Studies, 6(3), 308-322.

Baroncelli, A., \& Landoni, M. (2019). Imitation and entrepreneurial learning: Insights from academic spin-offs. Industry and Higher Education, 33(4), 233-245.

Rodrigues, C. B., \& Prideaux, B. (2018). A management model to assist local communities developing community-based tourism ventures: a case study from the Brazilian Amazon. Journal of Ecotourism, 17(2), 1-19.

Castro, C., \& Ferreira, F. A. (2019). Entrepreneurs' Self-Perception of Skills in Rural Tourism. European Journal of Tourism Research, 21, 50-68.

Friedrich, C., Glaub, M., Gramberg, K., \& Frese, M. (2006). Does training improve the business performance of small-scale entrepreneurs? An evaluative study. Industry and Higher Education, 20(2), 75-84.

Galvao, A. R., Marques, C. S., Ferreira, J. J., \& Braga, V. (2020). Stakeholders' role in entrepreneurship education and training programmes with impacts on regional development. Journal of Rural Studies, 74, 169-179.

Giampiccoli, A., \& Kalis, J. H. (2012). Tourism, food, and culture: Community-based tourism, local food, and community development in Mpondoland. Culture, Agriculture, Food and Environment, 34(2), 101-123.

Gunawan, Y., Eko, B., Yudistyana, R., \& Putri, D. T. (2020). Independent Community Building Model through Environmental-based Tourism Management in "Masdarling" Program. Economics Development Analysis Journal, 9(2), 208-219.

Gupta, S. (1989). Entrepreneurship development: the Indian case. Journal of small business management, 27(1), 67-69.

Haugh, H., \& Pardy, W. (1999). Community entrepreneurship in north east Scotland. International Journal of Entrepreneurial Behavior \& Research, 5(4), 163-172.

Imbaya, B., Nthiga, R., Sitati, N., \& Lenaiyasa, P. (2019). Capacity building for inclusive growth in community-based tourism initiatives in Kenya. Tourism Management Perspectives, 30, $11-18$.

Jaafar, M., Abu Bakar, S. P. S., \& Wan Daud, W. M. D. (2015). Training new housing entrepreneurs- A Malaysian scenario. In J. C. Sánchez-Garcia (Ed.), Entrepreneurship, Education and Training (pp. 225-244). Croatia: InTech.

Jaafar, M., Md Nor, S. \& Rasoolimanesh, S. M. (2015). Perception of young local residents toward sustainable conservation programmes: A case study of the Lenggong World Cultural Heritage Site. Tourism Management, 48, 154-163.

Jaafar, M., Kayat, K., Tangit, T. M., \& Yacob, M. F. (2013). Nature-based rural tourism and its economic benefits: A case study of Kinabalu National Park. Worldwide Hospitality and Tourism Themes, 5(4), 342-352. 
Jaafar, M., Md Noor, S., Mohamad, D., Jalali, A., \& Hashim, J. B. (2020). Motivational factors impacting rural community participation in community-based tourism enterprise in Lenggong Valley, Malaysia. Asia Pasific Journal of Tourism Research, 25(7), 697-710. doi: 10.1080/10941665.2020.1769696

Jalali, A., Jaafar, M., \& Ramayah, T. (2014). Entrepreneurial orientation and performance: the interaction effect of customer capital. World Journal of Entrepreneurship, Management and Sustainable Development, 10(1), 48-68.

Jalali, A., Jaafar, M., \& Thurasamy, R. (2013). Influence of entrepreneurial orientation on the financial performance: evidence from SMEs in Iran. Middle East Journal of Management, l(2), 168-185.

Jalali, A., Jaafar, M., \& Ramayah, T. (2020). Organization-stakeholder relationship and performance of Iranian SMEs: Examining the separate mediating role of innovativeness and risk-taking. International Journal of Islamic and Middle Eastern Finance and Management, 13(3), 417-4366.

Jalali, A., Thurasamy, R., \& Jaafar, M. (2017). The moderating effect of social capital in relation to entrepreneurial orientation and firm performance. In N. H. Ahmad, T. Ramayah, H. A. Halim \& S. A. Rahman (Eds.), Handbook of Research on Small and Medium Enterprises in Developing Countries (pp. 82-115). USA: IGI Global.

Jaramillo-Moreno, B. C., Sánchez-Cueva, I. P., Tinizaray-Tituana, D. G., Narváez, J. C., Cabanilla-Vásconez, E. A., Muñoz Torrecillas, M. J., \& Cruz Rambaud, S. (2020). Diagnosis of Administrative and Financial Processes in Community-Based Tourism Enterprises in Ecuador. Sustainability, 12(17), 7123. doi: https://doi.org/10.3390/su12177123

Johannisson, B. (2011). Towards a practice theory of entrepreneuring. Small business economics, 36(2), 135-150.

Johnson, P. A. (2010). Realizing rural community-based tourism development: Prospects for social economy enterprises. Journal of rural and community development, 5(1), 150-162.

Kayat, K., \& Zainuddin, N. F. A. (2016). Community-based Tourism Initiative in Rural Malaysia: Is it a Success? International Review of Management and Marketing, 6(7S), 242-249.

Kroon, J., \& Moolman, P. L. (1992). Entrepreneurship. South Africa: South Africa Central Publications.

Kurczewska, A., \& Mackiewicz, M. (2020). Are jacks-of-all-trades successful entrepreneurs? Revisiting Lazear's theory of entrepreneurship. Baltic Journal of Management, 15(3), 411-430.

Ladzani, W. M., \& Van Vuuren, J. J. (2002). Entrepreneurship training for emerging SMEs in South Africa. Journal of small business management, 40(2), 154-161.

Lee, T., \& Jan, F. (2019). Market segmentation based on the environmentally responsible behaviors of community-based tourists: Evidence from Taiwan's community-based destinations. International Journal of Tourism Research, 21(3), 400-411.

Lucchetti, V. G., \& Font, X. (2013). Community based tourism: Critical success factors. Retrieved from www.icrtourism.org/wp-content/uploads/2012/03/OP27.pdf

Mano, Y., Iddrisu, A., Yoshino, Y., \& Sonobe, T. (2012). How can micro and small enterprises in sub-Saharan Africa become more productive? The impacts of experimental basic managerial training. World Development, 40(3), 458-468.

Mgonja, J. T., Sirima, A., Backman, K. F., \& Backman, S. J. (2015). Cultural community-based tourism in Tanzania: Lessons learned and way forward. Development Southern Africa, 32(3), 377-391. 
Mitchell, J., \& Ashley, C. (2010). Tourism and Poverty Reduction. Pathways to Prosperity. London: Earthscan.

Mtapuri, O., \& Giampiccoli, A. (2013). Interrogating the role of the state and nonstate actors in community-based tourism ventures: toward a model for spreading the benefits to the wider community. South African Geographical Journal, 95(1), 1-15.

Mullins, L. J. (2010). Management and Organisational Behaviour. London: Pearson Education.

Nicely, A., \& Sydnor, S. (2015). Rural tourism development: Tackling a culture of local nonparticipation in a postslavery society. Journal of travel research, 54(6), 717-729.

North, D., \& Smallborne, D. (2006). Developing entrepreneurship and enterprise in Europe's peripheral rural areas: Some issues facing policy-makers. European Planning Studies, 14(1), 41-60.

Ogundele, O., Akingbade, W. A., \& Akinlabi, H. B. (2012). Entrepreneurship training and education as strategic tools for poverty alleviation in Nigeria. American International Journal of Contemporary Research, 2(1), 148-156.

Ooghe, H., \& De Prijcker, S. (2008). Failure processes and causes of company bankruptcy: a typology. Management Decision, 46(2), 223-242.

Osuagwu, L. (2006). Small Business and Entrepreneurship Management. Lagos: Grey Resources Limited.

Pato, L., \& Kastenholz, E. (2017). Marketing of rural tourism-a study based on rural tourism lodgings in Portugal. Journal of Place Management and Development, 10(2), 121-139.

Peredo, A. M., \& Chrisman, J. J. (2006). Toward a theory of community-based enterprise. Academy of management Review, 31(2), 309-328.

Rasoolimanesh, S. M., Dahalan, N., \& Jaafar, M. (2016). Tourists' perceived value and satisfaction in a community-based homestay in the Lenggong Valley World Heritage Site. Journal of Hospitality and Tourism Management, 26, 72-81.

Schendel, D., \& Hitt, M. A. (2007). Introduction to volume 1. Strategic Entrepreneurship Journal, $1(1 \& 2), 1-6$.

Scheyvens, R. (2002). Backpacker tourism and third world development. Annals of tourism research, 29(1), 144-164.

Sebele, L. S. (2010). Community-based tourism ventures, benefits and challenges: Khama rhino sanctuary trust, central district, Botswana. Tourism management, 31(1), 136-146.

Stone, L. (1989). Cultural cross-roads of community participation in development: A case from Nepal. Human Organisation, 48(3), 206-213.

Stone, L. S., \& Stone, T. M. (2011). Community-based tourism enterprises: challenges and prospects for community participation; Khama Rhino Sanctuary Trust, Botswana. Journal of Sustainable Tourism, 19(1), 97-114.

Sullivan, R. (2000). Entrepreneurial learning and mentoring International Journal of Entrepreneurial Behaviour \&Research, 6(3), 160-167.

Taylor, S. R. (2017). Issues in measuring success in community-based Indigenous tourism: elites, kin groups, social capital, gender dynamics and income flows. Journal of Sustainable Tourism, 25(3), 433-449.

Tosun, C. (2000). Limits to community participation in the tourism development process in developing countries. Tourism management, 21(6), 613-633.

Zielinski, S., Jeong, Y., \& Milanés, C. B. (2020). Factors that influence community-based tourism (CBT) in developing and developed countries. Tourism Geographies, doi: 10.1080/14616688.2020.1786156 